\title{
MOTIVASI PELAKU ONLINE HUMAN TRAFFICKING
}

\author{
Rheta Zuliana ${ }^{1}$, Sawi Sujarwo ${ }^{2}$ \\ MahasiswaUniversitas Bina Darma ${ }^{1}$, Dosen Universitas Bina Darma ${ }^{2}$ \\ Jalan A. Yani No. 3 Palembang \\ Sur-el : rhetazuliana@gmail.com ${ }^{1}$, sawi_sujarwo@binadarma.ac.id ${ }^{2}$
}

\begin{abstract}
This study aims to find out more about the dynamics of psychology and motivation factors of online human trafficking perpetrators on two subjects of early adult men who became prisoners Dirreskrimum Polda South Sumatra. To achieve research objectives researchers used a qualitative approach. The technique was used in 2 men aged 28 and 31 who had been in custody for several months. Based on the results of research known that the motivation of online human trafficking is divided into two, i.e. internal motivation and external motivation. Internal motivation of online human trafficking actors is a form of interest and lifestyle expression, while external motivation of human trafficking is the influence of peers, family demands and economic factors. Other findings from this study are the similarity of educational background, and economic causes. In addition, it was found that the influence of drugs and suicidal desires that arise due to heavy burden of the subject's life. But it does not make them desperate in the pursuit of future dreams and become a reference to be able to improve themselves and become a better person.
\end{abstract}

Keywords : motivation, perpetrators, online human trafficking

\begin{abstract}
Abstrak : Penelitian ini bertujuan untuk mengetahui lebih dalam mengenai dinamika psikologi dan faktor-faktor motivasi pelaku online human trafficking pada dua orang subjek laki-laki dewasa awal yang menjadi tahanan Dirreskrimum Polda Sumatera Selatan. Untuk mencapai tujuan penelitian peneliti menggunakan pendekatan kualitiatif. motivasi eksternal. Motivasi internal pelaku online human trafficking adalah bentuk minat dan ekspresi gaya hidup, sedangkan motivasi eksternal pelaku online human trafficking adalah pengaruh teman sebaya, tuntutan keluarga dan faktor ekonomi.Teknik tersebut digunakan pada 2 orang laki-laki yang berusia 28 dan 31 tahun yang telah menjadi tahanan selama beberapa bulan. Berdasarkan hasil penelitian diketahui bahwa motivasi pelaku online human trafficking dibagi menjai dua, yaitu motivasi internal dan Temuan lain dari penelitian ini adalah adanya kesamaan latar belakang pendidikan, dan penyebab ekonomi.Selain itu, ditemukan pula bahwa adanya pengaruh obat-obatan terlarang dan keinginan bunuh diri yang muncul dikarenakan beban hidup subjek yang berat. Namun hal tersebut tidak membuat mereka putus asa dalam mengejar impian masa depan dan menjadi acuan untuk bisa memperbaiki diri dan menjadi orang yang lebih baik
\end{abstract}

Kata kunci : motivasi, pelaku, online human trafficking

\section{PENDAHULUAN}

Banyak hal positif yang dapat kita temui dari pemanfaatan internet misalnya sebagai pusat pencarian dan penyediaan data serta alat komunikasi yang sangat memfasilitasi masyarakat. Tidak hanya hal positif saja, banyak pula hal negatif yang dapat ditemui pada pemanfaatan internet misalnya pembajakan atau plagiarisme yang dilakukan oleh seseorang terhadap karya orang lain, ada pula yang memanfaatkan internet untuk menipu orang lain melalui toko 
ataupun online system yang memperdagangkan manusia.Perdagangan orang (trafficking) adalah bentuk modern dari perbudakan manusia. Perdagangan orang juga merupakan salah satu bentuk perlakuan terburuk dan pelanggaran harkat dan martabat manusia, dengan sendirinya merupakan pelanggaran hak asasi manusia (Nurhenny, 2010). Perdagangan manusia dapat dikatakan sebagai perbudakan dan juga melanggar hak asasi manusia. Kondisi ini berkembang pada masyarakat ekonomi yang memiliki tingkat ekonomi lemah, pemahaman agama atau moralitas yang kurang, dan bergantung pada kelompok masyarakat ekonomi kuat. Alasan yang diberikan oleh korban umumnya perbuatan mereka adalah legal dengan dasar perjanjian. Pelanggaran hak asasi manusia yang berupa perbudakan umumnya berupa perampasan kebebasan dari seseorang, yang dilakukan oleh kelompok ekonomi kuat kepada kelompok ekonomi lemah. Maka, atas dasar itu pencegahan perdagangan orang dalam perspektif pelanggaran hak asasi manusia harus dilakukan secara komprehensif dan integral, yang dapat dilakukan melalui tataran kebijakan hukum pidana dengan cara legislasi, eskekusi, dan yudikasi sanksi pidana, tetapi dalam pelaksanaannya perbuatan ini masih banyak dilakukan, bahkan dijadikan mata pencarian atau sumber nafkah kehidupan keluarga. undangundang hak asasi manusia, dimana para pelaku akan dikenakan sanksi pidana, dimana dilihat dari efektifitasnya ternyata peraturan ini tidak efektif (Kansil, 2009). Penyebabnya tentu berbagai macam alasan, dapat disebabkan faktor-faktor lainnya, sehingga proses penegakan hukum yang tidak efektif atau ketidakpercayaan masyarakat terhadap institusi hukum, karena menganggap tidak akan mendapatkan keadilan (Priyanto, 2013).

Menurut Mangkunegara

menjelaskan bahwa kebutuhan dapat didefinisikan sebagai suatu kesenjangan atau pertentangan yang dialami antara suatu kenyataan dengan dorongan yang ada dalam diri. Banyak sekali para ahli yang menjelaskan tentang kebutuhan manusia, salah satu yang paling dikenal luas adalah penjelasan kebutuhan manusia yang dikemukakan oleh Abraham Maslow. Maslow (Alwisol, 2009) berasumsi bahwa hampir setiap manusia, dan sudah barang tentu dalam hampir setiap bayi yang baru lahir, terdapat kemauan yang aktif kearah kesehatan, impuls kearah pertumbuhan, atau kearah aktualisasi potensi-potensi manusia.

Berdasarkan teori hirarki kebutuhan, Maslow mencoba untuk menjelaskan mengenai beberapa kebutuhan yang dapat 
memotivasi seseorang berperilaku. Maslow (Alwisol, 2009) mengungkapkan terdapat dua macam kebutuhan dalam diri seseorang, yaitu kebutuhan dasar dan kebutuhan untuk bertumbuh (metaneed). Hirarki kebutuhan menjelaskan bagaimana seseorang akan berperilaku untuk memenuhi kebutuhannya dengan cara bertingkat, yaitu dimulai dari kebutuhan pada tingkat yang paling rendah dan paling dasar baru kemudian naik ke kebutuhan yang memiliki tingkat lebih tinggi.

Menurut Maslow (Alwisol, 2009) kebutuhan orang tidak bergerak secara garis lurus dari kebutuhan fisiologis terpuaskan kemudian beralih ke kebutuhan rasa aman terpuaskan lalu beralih ke kebutuhan dicintai dan mencintai dan seterusnya, tapi memungkinkan bagi seseorang untuk memiliki kepuasan pada suatu kebutuhan pada jenjang yang lebih tinggi, tidak peduli seberapa tinggi jenjang yang sudah dilewatinya. Dalam hirarki kebutuhan Maslow terdapat kebutuhan fisiologis, rasa aman, dicintai dan mencintai, dan harga diri sebagai kebutuhan dasar yang dimiliki manusia. Kebutuhan untuk bertumbuh berdiri sendiri karena tidak semua orang mampu mencapai pada pemenuhan kebutuhan ini, untuk memenuhi kebutuhan ini seseorang harus dapat memenuhi kebutuh an dasarnya secara relatif terpuaskan. Hal ini sesuai dengan yang dirasakan oleh pelaku Online Human Trafficking yang termotivasi memperdagangkan manusia untuk menangani masalah rendahnya perekonomian mereka dan mendapatkan penghasilan lebih dengan cara menipu orang lain untuk diekploitasi guna memenuhi kebutuhan dasar mereka. Seperti yang terjadi pada subjek penelitian yang merupakan seorang lelaki tahanan Polda Sumsel.

Peneliti ingin mengetahui seberapa jauh media sosial membantu seseorang menjadi termotivasi melakukan hal negatif yakni pemanfaatan media sosial sebagai akses yang membantu berjalannya proses human trafficking. Peneliti juga tertarik mengenai faktor - faktor yang memotivasi seseorang melakukan online human trafficking. Untuk mengetahui hal itu maka perlu dilakukan penelitian menggunakan metode kualitatif yaitu suatu pendekapendekatan secara mendalam kepada subjek penelitian dan berdasarkan kasus yang terjadi di lapangan maka penelitian ini menggunakan pendekatan studi kasus.

Menurut Suprihanto (2003), terdapat aspek- aspek dari motivasi adalah: a)keadaan yang mendorong tingkah laku ( motivating states ); b) tingkah laku yang di dorong oleh keadaan tersebut (motivated behavior ); c) 
dan tujuan dari pada tingkah laku tersebut ( goals or ends of such behavior).

Menurut Herlina (2012), Ada tiga aspek dalam motivasi, yaitu : 1. Keadaan yang mendorong, yang ada dalam organisme, yang muncul karena adanya kebutuhan tubuh, stimulus lingkungan, atau kejadian mental seperti berpikir dan ingatan. 2. Tingkah laku, yang dibangkitkan dan diarahkan oleh keadaan tadi. 3. Tujuan yang menjadi arah dari tingkah laku. Jadi motif membangkitkan tingkah laku dan mengarahkannya pada tujuan yang sesuai. Selain itu, motivasi merupakan kompleksitas proses fisik fisiologi yang bersifat energetik (dilandasai dengan adanya energi), keterangsangan (disulut oleh stimulus), dan keterarahan (tertuju pada sasaran).

Menurut Chernis dan Goleman (2001), motivasi memiliki aspek-aspek sebagai berikut : 1. Dorongan mencapai sesuatu Suatu kondisi yang mana individu berjuang terhadap sesuatu untuk meningkatkan dan memenuhi kebutuhannya. 2. Komitmen. Salah satu aspek yang cukup penting dalam proses mencapai tujuan. Orang yang memiliki komitmen memiliki kesadaran untuk mengerjakan tugasnya dalam mencapai tujuan. 3. Optimis. Suatu sikap yang gigih dalam mengejar tujuan tanpa perduli adanya kegagalan dan kemunduran. Tujuan Penelitian untuk mengetahui resiliensi pada seorang wanita dewasa awal penyandang cerebral palsy dan untuk mengetahui faktor - faktor yang mempengaruhi resiliensi pada penyandang cerebral palsy untuk mencapai resiliensi.

Peneliti berharap hasil penelitian ini dapat menambah pengetahuan bagi pengembangan ilmu psikologi, khususnya psikologi sosial dan psikologi perkembangan, psikologi klinis, psikologi faal dan psikologi anak berkebutuhan khusus serta menambah pengetahuan mengenai resiliensi pada wanita dewasa penyandang cerebral palsy

\section{METODOLOGI PENELITIAN}

Penelitian kualitatif adalah keterkaitan spesifik pada studi hubungan sosial yang berhubungan dengan fakta dari pluralisasi dunia kehidupan. Metode ini diterapkan untuk melihat dan memahami subjek dan objek penelitian yang meliputi orang, lembaga berdasarkan fakta yang tampil secara apa adanya. Melalui pendekatan ini akan terungkap gambaran mengenai aktualisasi, realitas sosial dan persepsi sasaran penelitian (Gunawan, 2013). Metode pendekatan kualitatif yaitu pendekatan yang digunakan untuk mendeskripsikan, mengambarkan, atau melukiskan secara 
sistematis dari gejala atau fenomena yang menjadi objek penelitian.

Creswell (Herdiansyah, 2015) menyatakan bahwa studi kasus (case study) adalah suatu model yang menekankan pada eksplorasi dari suatu "system yang saling terkait satu sama lain" (bounded system) pada beberapa hal dalam satu kasuus secara mendetail, disertai dengan penggalian data secara mendalam yang melibatkan beragam sumber informasi yang kaya akan konteks(Arikunto, 2006).

Secara lebih dalam, case study merupakan suatu model yang bersifat komprehensif, intens, memerinci dan mendalam serta kontemporer (Herdiansyah, 2015). Penelitian ini berorientasi pada dua orang laki-laki dewasa awal yang merupakan pelaku online human trafficking. Pada penelitian kualitatif ini peneliti lebih memfokuskan diri dan bermaksud untuk memahami permasalahan secara mendalam serta menemukan suatu pola yang berhubungan dengan motivasi pelaku online human trafficking. Penelitian ini menggunakan penelitian studi kasus, agar peneliti dapat mengetahui motivasi pelaku online human trafficking ditinjau dari faktor - faktor yang mempengaruhi motivasi pelaku online human trafficking.
Ada empat sumber data dalam penelitian kualitatif yaitu, subjek, informan pelaku dan informan tahu, written document dan unwritten document. Penelitian dapat diterapkan dan dilakukan pada berbagai subjek yang ada, tetapi untuk memudahkan peneliti maka penelitian yang dilakukan hanya memfokuskan pada dua orang laki-laki dewasa awal yang merupakan pelaku online human trafficking yaitu A dan $\mathrm{H}$.

Sedangkan informan tahu yang dimaksudkan dalam penelitian ini adalah orang-orang disekitar subjek penelitian yang bersedia menjadi narasumber tambahan guna melengkapi data yang belum lengkap dan kepentingan cross-check dalam rangka validasi data termasuk disini adalah dua orang penyidik yang menangani kasus subjek sebagai anggota Dirreskrimum Polda Sumsel. Informan pelaku dalam penelitian ini adalah orang - orang yang memiliki hubungan dengan subjek yaitu keluarga subjek.

Teknik yang digunakan dalam penelitian ini adalah gabungan dari teknik observasi, wawancara dan dokumentasi. Teknik pengumpulan data yang dipakai oleh peneliti adalah passive participation (partisipasi pasif). Jadi dalam hal ini peneliti datang di tempat kegiatan orang yang diamati, tetapi tidak ikut terlibat dalam kegiatan tersebut (Sugiyono,2013). Teknik pengumpulan data yang dilakukan dalam penelitian ini ialah 
wawancara semiterstruktur (semistructure interview). Jenis wawancara ini sudah termasuk dalam kategori in-dept interview, dimana pelaksanaannya lebih bebas bila dibandingkan dengan wawancara terstruktur. Dalam melakukan wawancara, peneliti perlu mendengarkan secara teliti dan mencatat apa yang dikemukakan oleh informan (Sugiyono,2013). Dokumentasi merupakan catatan peristiwa yang sudah berlalu. Dokumen bisa berbentuk tulisan, gambar, atau karya - karya monumental dari seseorang. Dokumen yang berbentuk tulisan misalnya catatan harian, sejarah kehidupan dan biografi. Dokumen yang berbentuk gambar misalnya foto, gambar hidup, sketsa dan catatan lain yang berhubungan dengan penelitian. Dokumen yang berbentuk karya seni, yang dapat berupa gambar, patung, film, dan lain-lain. Dokumentasi dapat berupa surat - surat , gambar foto dan catatan lain yang berhubungan dengan penelitian (Sugiyono, 2012).

\section{Hasil dan Pembahasan}

Berdasarkan hasil wawancara dengan subjek penelitian subjek $\mathrm{A}$ dan $\mathrm{H}$ serta dibantu oleh informasi dari informan tahu, diperoleh beberapa tema yang mengarah pada jawaban atas pertanyaan penelitian yang akan diuraikan secara sistematis. Tema-tema tersebut mengisi jawaban atas pertanyaan mengenai motivasi pelaku online human trafficking ditinjau dari faktor - faktor yang mempengaruhi motivasi. Keseluruhannya merupakan pandangan dari pengalaman yang terjadi pada subjek sebagai pelaku online human trafficking.

Menurut Nurhenny (2010), perdagangan orang (human trafficking) adalah bentuk modern dari perbudakan manusia. Perdagangan orang juga merupakan salah satu bentuk perlakuan terburuk dan pelanggaran harkat dan martabat manusia, dengan sendirinya merupakan pelanggaran hak asasi manusia.

Pengertian tersebut meliputi menawarkan, mendapatkan atau menyediakan seseorang untuk prostitusi. Diskriminasi terhadap wanita berarti setiap pembedaan, pengucilan atau pembatasan yang dibuat atas dasar jenis kelamin, yang mempunyai pengaruh atau tujuan untuk mengurangi atau menghapuskan pengakuan, penikmatan atau penggunaan hak-hak asasi manusia dan kebebasankebebasan pokok di bidang politik, ekonomi, sosial, budaya, sipil atau apapun lainnya oleh perempuan, terlepas dari status perkawinan mereka, atas dasar persamaan antara laki-laki dan perempuan (Luhulima \& Tridewanti, 2000).

Kaylor (2015) dengan penelitiannya

yang berjudul Psychological Impact of 
Human Trafficking and Sex SlaveryWorldwide : Empowerment and Intervention, menyimpulkan bahwa Human Trafficking sudah mewabah di dunia, target negara yang menjadi tujuannya adalah negara yang menjadi kota transit, yang memiliki banyak pengungsi, orang-orang dengan trauma mendalam, tunawisma dan imigran illegal. Dampak psikologis yang biasanya terjadi pada korban adalah, Post Traumatic Stress Disorder (PTSD), gangguan kecemasan, gangguan panik, depresi, keinginan bunuh diri dan Stockholm Syndrome. Menurut Pertiwi (2013) faktor-faktor penyebab perdagangan manusia adalah faktor ekonomi, faktor ekologis, faktor sosial budaya dan ketidakadaan kesetaraan gender. Kedua subjek mengalami pengalaman yang tidak menyenangkan seperti mendapatkan tekanan dari keluarga subjek yang menjadikan mereka sebagai tulang punggung keluarga yang harus memenuhi kebutuhan orang tua dan saudarasaudaranya. Hal ini menunjukkan bahwa subjek memiliki indikator untuk terdorong atau termotivasi dalam memenuhi kebutuhan hidup secara instant dengan melakukan Online Human Trafficking.

Munthe (2011), melakukan penelitian tentang Perdagangan Orang (Trafficking) sebagai Pelanggaran Hak
Asasi Manusia menyimpulkan bahwa perdagangan orang sering kali dilakukan oleh orang yang memiliki jaringan secara nasional maupun internasional, mempunyai kekuasaan, kuat secara fisik, dan arogan. Karna orang yang menjadi korban perdagangan orang adalah orang yang ekonominya yang lemah, pendidikan masih rendah. Umumnya korban perdagangan orang (trafficking) itu adalah orang dekat dari pelaku.

Dampak psikologis yang biasanya terjadi pada korban adalah, Post Traumatic Stress Disorder (PTSD), gangguan kecemasan, gangguan panik, depresi, keinginan bunuh diri dan Stockholm Syndrome. Stress Disorder (PTSD), gangguan kecemasan, gangguan panik, depresi, keinginan bunuh diri dan Stockholm Syndrome. Menurut Pertiwi (2013) faktor-faktor penyebab perdagangan manusia adalah faktor ekonomi, faktor ekologis, faktor sosial budaya dan ketidakadaan kesetaraan gender. Kedua subjek mengalami pengalaman yang tidak menyenangkan seperti mendapatkan tekanan dari keluarga subjek yang menjadikan mereka sebagai tulang punggung keluarga yang harus memenuhi kebutuhan orang tua dan saudara-saudaranya. Hal ini menunjukkan bahwa subjek memiliki indikator untuk terdorong atau termotivasi 
dalam memenuhi kebutuhan hidup secara instant dengan melakukan Online Human Traffiking.

Motivasi merupakan keadaan dalam diri individu atau organisme yang mendorong perilaku ke arah tujuan. Menurut Munandar (2001) motivasi juga merupakan suatu proses ketika kebutuhan mendorong seseorang untuk melakukan serangkaian kegiatan yang mengarah ketercapainya tujuan tertentu. Menurut Santrock (Rachman, 2015), motivasi adalah proses yang memberi semangat, arah, dan kegigihan perilaku. Artinya, perilaku yang memiliki motivasi adalah perilaku yang penuh energi, terarah, dan bertahan lama. Terry (Notoatmodjo, 2010) motivasi adalah keinginan yang terdapat pada diri seorang individu yang

mendorongnya untuk melakukan perbuatan-perbuatan, tindakan, tingkah laku atau perilaku. Kemudian Munandar (2010) mendefinisikan motivasi adalah suatu proses dimana kebutuhan-kebutuhan mendorong seseorang untuk melakukan serangkaian kegiatan yang mengarah ke tercapainya tujuan tertentu. Sebuah motif atau motivasi manusia untuk melaksanakan sesuatu dan mencapai suatu tujuan selalu dilatarbelakangi oleh sebuah kebutuhan dari manusia itu sendiri.
Dari penjelasan diatas didapatkan kesimpulan bahwaun metode penelitian ini peneliti akan meneliti tentang motivasi pelaku Online Human Trafficking, adapmenggunakan metode penelitian kualitatif dengan pendekatan studi kasus. Perbedaan penelitian ini dengan penelitian sebelumnya adalah dari subjek yang merupakan dua orang laki-laki berusia 31 tahun dan 28 tahun, metode yang digunakan adalah triangulasi. Subjek penelitian yang sebelumnya belum pernah menjadi subjek penelitian apapun. Oleh karena itu peneliti meyakini bahwa penelitian ini dapat dipertanggungjawabkan.

\section{Kesimpulan}

Berdasarkan hasil analisis yang dilakukan peneliti dapat ditarik kesimpulan bahwa subjek penelitian dipengaruhi oleh beberapa faktor-faktor motivasi yang dapat dilihat dari tema yang muncul baik dari sisi eksternal yakni faktor lingkungan, teman sebaya, dan ekonomi serta dari sisi internal yakni faktor pembawaan perilaku individu, pengalaman masa lampau dan orientasi masa depan.

Dapat ditarik kesimpulan bahwa dinamika psikologi laki-laki pelaku online human trafficking menjadi tipe individu yang termotivasi (motivated) melalui faktor-faktor yang mempengaruhinya menjadi pelaku 
online human trafficking dilihat dari hasil wawancara dan observasi yang sudah dilakukan. Subjek pun mampu melakukan apapun demi mencapai tujuan-tujuan nya baik dengan hal positif seperti bekerja di kantor maupun hal negatif seperti menjadi pelaku online human trafficking.

\section{Daftar Pustaka}

Alwisol. 2009. Psikologi Kepribadian edisi revisi. Malang : UMM Press.

Arikunto, S. 2006. Metode Penelitian Kualitatif. Jakarta: Bumi Aksara

Chernis, C \& Goleman, D. 2001.The Emotionally Intelligent Workplace,San Fransisco: Jossey Bass a Willey Company

Gunawan, Iman. 2013. Metode Penelitiaan Kualitatif :Teori dan Pratilik. Jakarta: Bumi Aksara

Herdiansyah,H.2015.Metode Penelitian Kualitatif Untuk Ilmu Psikologi. Jakarta: Salemba Humanika

Herlina. (2010). Minat Belajar. Jakarta: Bumi Aksara.

Kansil.2002. Pengantar Ilmu Hukum, Jakarta, Balai Pustaka

Kaylor, Leah.2015. Psychological Impact of Human Trafficking and Sex Slavery Worldwide:Empowerment and Intervention. Intern from John Jay College of Criminal JusticeNew York, NY

Luhulima, A. S. dan Kunthi T, 2000, Pola Tingkah Laku Sosial Budaya dan Kekerasan Terhadap Perempuan, Kelompok Kerja Kerja Vomvention Watch, Pusat Kajian Wanita dan Jender Universitas Indonesia, Jakarta.

Mangkunegara, A.A. Anwar Prabu . (2011). Manajemen Sumber Daya Manusia Perusahaan. Bandung : Rosda

Munandar. 2001.Psikologi Industri dan Organisasi. Depok.PenerbitUniversitasIndonesia (UIPress).

Munthe, 2015. Perdagangan Orang (Traffiking) sebagai Pelanggaran Hak Asasi Manusia, Jurnal Pendidikan Ilmu-Ilmu Sosial, Universitas Medan Area. 
Notoatmodjo, S.2010. Metodologi Penelitian

Kesehatan. Jakarta: Rineka Cipta

Priyanto, 2012. Kriminologi, Penerbit Ombak, Yogyakarta,

Rahman, A. 2011. Human Trafficking in the Era of Globalization : The Case of Trafficking in The Global Market Economy. Transcience Journal, Malaysia. Edisi 2. No. 4. Vol. 1. Januari. Hal 1-10.

Rahman, A.A. (2016). Metode Penelitian.

Jakarta.

Rodaskarya

Santrock, J.W. (2007). Psikologi Perkembangan. Edisi 11 Jilid 1.

Jakarta: Erlangga.

Sugiyono. (2012). Metode Penelitian Kualitatif dan R\&D. Bandung: Alfabeta

Suprihanto John, dkk., 2003. Perilaku Organisasional. Yogyakarta: Sekolah Tinggi Ilmu Ekonomi YKPN.

Suprihanto, dkk. 2003. Perilaku Organisasional. Yogyakarta: STI 
